\title{
The Analysis of Biocatalytic Properties of a Proteolytic Enzyme under the Influence of Physical Factors
}

\author{
Ivan Brashko, Irina Tretyakova, Sergey Tikhonov*, Natalya Tikhonova, and Vladimir \\ Lazarev
}

Ural State University of Economics, 620144 Ekaterinburg, Russian Federation

\begin{abstract}
Due to the relevance of biotechnological methods application in the meat processing industry, consisting in the reuse of collagen-containing raw materials, as well as the use of enzymes and enzyme preparations to improve quality and extend the shelf life, which is confirmed by the research results conducted in the field of food biotechnology, the purpose of the work was formulated. It consists in studying the changes in the biocatalytic activity of the collagenase enzyme after treatment with a blue light spectrum. In the course of the work, it was revealed that the activity of the collagenase enzyme, which was treated with a blue light spectrum, has a wider optimum $\mathrm{pH}$ in comparison with the control samples. Treatment of the solution with blue light collagenase with a luminous flux of $35 \mu \mathrm{W} / \mathrm{cm} 2$ for 1 hour increases the optimum biocatalytic activity of the enzyme, which is confirmed by studies conducted in two alternative methods (according to Anson and Telishevskaya). The experimental data showed that the activity of the collagenase enzyme in the experimental samples increases from 10 to $20 \%$ under the influence of table salt in concentrations up to $3.5 \%$ compared to the control group.
\end{abstract}

\section{Introduction}

It is known that physical factors (mechanical, wave) can affect the activity of enzymes, for example, incubation of the studied enzyme preparations in $0.5 \%$ hydrochloric acid solution significantly reduces the activity of amylase and lipase. In the enzyme preparations produced in the form of tablets, the greatest decrease in the activity of amylase and lipase after incubation in hydrochloric acid is observed, which indicates a weak acid-resistant property of the shells of the studied drugs. This is due to the destruction of the protective shell and partial inactivation of the enzymes in the studied preparations [1].

Scientists have studied the effects of wave and optical effects on enzyme preparations in order to increase the activity of target enzymes. The results of light treatment effect with wavelengths from the range of 364-980 nm of the enzyme preparation Amilorizin P10x on its amylolytic ability showed that photo-treatment under experimental conditions allowed to

\footnotetext{
* Corresponding author: tihonov75@bk.ru
} 
increase the amount of hydrolyzed starch by 20-70\% compared to the control, depending on the wavelength of light used for processing [2].

Processing with visible-range monochromatic light significantly affects the technological properties of brewer's yeast and top fermentation, changing the nature of reproduction of the population of these microorganisms. The degree of such influence depends significantly on the wavelength of the light used for processing. By choosing a specific wavelength, you can change specific targets for yeast reproduction: the increase in the total number of cells and the consumption intensity of nutrient medium components. Processing with monochromatic light allows intensifying the process of top yeast development with low technological characteristics [3].

The researches of acoustic and light exposure effect on the enzyme preparation "APSubitilin P" showed that the starch content during acoustic treatment $(2000 \mathrm{~Hz})$ increased by 3 times, and during light treatment $(346 \mathrm{~nm})$ by 6 times. The amylolytic capacity of sound processing (1200-14000 Hz) was reduced by $50 \%$, and when exposed to blue light $(750 \mathrm{~nm})$, the reduction in amylolytic capacity reached $70 \%$ [4].

The study revealed the inhibitory effect of red and blue light on the content of transcripts of the mitochondrial and cytoplasmic forms of aconitase on the level of transcription of aco 1 genes in green corn leaves and showed a decrease in the concentration of their mRNA under the influence of a physical factor, which is associated with a change in the rate of aconitate hydratase functioning under these conditions. The results indicate the participation of the phytochromic and cryptochromic systems in the regulation of aconitate hydratase functioning [5].

In the studies conducted on the effect of light on linear growth, biomass accumulation and melanin synthesis in I. obliquus under the influence of coherent and incoherent light, the greatest stimulating effect was found when the mycelium was irradiated with blue light. Laser light exposure has a greater effect on the growth and accumulation of biomass in the mycelium of the fungus than incoherent light exposure. Light treatment significantly reduces the duration of fermentation [6]. The study of blue and red light influence on the physiological and biochemical characteristics of wheat plants showed that the influence of blue light stimulated the synthesis of proteins, and the synthesis of carbohydrates in wheat cells was affected by the radiation of the red light spectrum [7]. The influence of the blue light spectrum on dynamic growth is also confirmed in a study on the rate of photosynthesis under the influence of red and blue light, when irradiated with blue light, growth indicators increase, when exposed to red light, the effect slows down [8].

\section{Materials and methods}

In this regard, the aim of this work is to study the catalytic activity of the collagenase enzyme after treatment with blue light and under the influence of physical factors.

The object of the study is determined to be collagenase type I, which has the form of a fine sterile white powder with an activity of $125 \mathrm{u} / \mathrm{mg}$, and as a collagen-containing raw material, the skin of broiler chickens. The objects were divided into control and experimental groups. The control group with the collagenase enzyme was not treated with light, the experimental group with the collagenase enzyme was treated with blue light for 1 hour with a luminous flux of $35 \mu \mathrm{W} / \mathrm{cm} 2$.

The activity of the enzyme was studied using the Anson method [9] and the Telishevskaya express method [10], which consist in the hydrolysis of gelatin with a collagenase solution. According to the method, the study should be carried out at a temperature of $37^{\circ} \mathrm{C}$. However, this negatively affects the gelatin, destroying its structure, which does not allow to determine the activity of the enzyme. In this regard, a temperature of $24{ }^{\circ} \mathrm{C}$ was selected to study the activity of collagenase. The collagenase solution must be prepared in advance in water 
purified by distillation in the ratio $1: 10,1: 20,1: 30$ etc. The activity of the enzyme is determined by applying drops of the solution to the gelatin film with their delay on it for 10 minutes, after which they are washed off with water. Places with the applied solution are visually evaluated. According to the Anson method, the proteolytic activity of the enzyme is calculated by hydrolysis of gelatin.

\section{Results}

The $\mathrm{pH}$ environment in which the chemical reaction takes place affects the activity of the enzyme. Each enzyme is characterized by a special $\mathrm{pH}$ indicator, at which the peak of its activity is recorded. The deviation of the $\mathrm{pH}$ from the optimal one leads to a decrease in the reaction rate due to changes in the ionization of the functional amino acid residues of the protein molecule. A change in the reaction of the medium to the acid side causes a shift in the proton of free amino groups, causing a change in the rate of attachment of the substrate and its specificity. If the $\mathrm{pH}$ changes significantly, the enzyme undergoes denaturation and loses its biocatalytic activity. Table 1 contains indicators reflecting the relationship between $\mathrm{pH}$ and the activity of the collagenase enzyme at a temperature optimum of $42{ }^{\circ} \mathrm{C}$.

Table 1. The effect of $\mathrm{pH}$ on the Activity of Control and Experimental Samples of the Collagenase Enzyme at Temperature of $42^{\circ} \mathrm{C}, \%$.

\begin{tabular}{|c|c|c|c|}
\hline \multicolumn{2}{|c|}{ Control } & \multicolumn{2}{c|}{ Experiment } \\
\hline $\mathrm{pH}$ & $\begin{array}{c}\text { Activity according to } \\
\text { the Anson method, } \%\end{array}$ & $\mathrm{pH}$ & $\begin{array}{c}\text { Activity according to } \\
\text { the Anson method, } \%\end{array}$ \\
\hline 5 & 90 & 5 & 96 \\
\hline 6 & 94 & 6 & 99 \\
\hline 7 & 97 & 7 & 100 \\
\hline 8 & 100 & 8 & 98 \\
\hline 9 & 98 & 9 & 96 \\
\hline 10 & 89 & 10 & \\
\hline
\end{tabular}

From the data presented in Table 1, it follows that when exposed to blue light on the studied objects, in the control group at $\mathrm{pH}=8$, the activity of the enzyme is $100 \%$, in the experimental group this indicator is achieved at a $\mathrm{pH}$ range from 7 to 8 .

When conducting studies according to the method [19] at a maintained temperature of 42 ${ }^{\circ} \mathrm{C}$, the manifestation of activity in the control samples is $1: 270$, in the experimental samples $-1: 320$, which correlates with the data obtained from studies conducted according to the method [18] and indicates a difference in enzyme activity between the control and experimental groups of 29,000 units/mg.

The results of $\mathrm{pH}$ effect on the activity of the enzyme according to the method of Telishevskaya L. Ya. are presented in Table 2.

Table 2. The relationship Between $\mathrm{pH}$ and the Activity of Control and Experimental Samples of the Collagenase enzyme at a Temperature of $42^{\circ} \mathrm{C}, \%$.

\begin{tabular}{|c|c|c|c|}
\hline \multicolumn{2}{|c|}{ Control } & \multicolumn{2}{c|}{ Experiment } \\
\hline $\mathrm{pH}$ & $\begin{array}{c}\text { Activity according to the } \\
\text { Telishevskaya method, } \%\end{array}$ & $\mathrm{pH}$ & $\begin{array}{c}\text { Activity according to the } \\
\text { Telishevskaya method, } \%\end{array}$ \\
\hline 5 & 90 & 5 & 96 \\
\hline 6 & 94 & 6 & 99 \\
\hline 7 & 97 & 7 & 100 \\
\hline 8 & 100 & 8 & 98 \\
\hline 9 & 98 & 9 & 96 \\
\hline 10 & 89 & 10 & \\
\hline
\end{tabular}


While studying in alkaline environment, the activity of the experimental samples was $96 \%$, in the control samples it was $7 \%$ lower. In a neutral environment, the indicators in both groups were $100 \%$.

An increase in temperature leads to a change in the rate of the chemical reaction, this is due to an increase in the speed of the molecules and their interaction, which leads to a change in the active center of the enzyme.

The temperature effect on the activity of the collagenase enzyme at an optimum $\mathrm{pH}$ of 8 is shown in Table 3.

Table 3. The Effect of Temperature on the Activity of Control and Experimental Samples of the Collagenase Enzyme at an Optimum $\mathrm{pH}$ of 8.

\begin{tabular}{|c|c|c|c|}
\hline & \multicolumn{2}{|c|}{ Experiment } \\
\hline $\mathrm{t},{ }^{\circ} \mathrm{C}$ & $\begin{array}{c}\text { Activity according to } \\
\text { the Telishevskaya } \\
\text { method, } \%\end{array}$ & $\mathrm{t},{ }^{\circ} \mathrm{C}$ & $\begin{array}{c}\text { Activity according to } \\
\text { the Telishevskaya } \\
\text { method, } \%\end{array}$ \\
\hline 0 & 0 & 0 & 0 \\
\hline 10 & 28 & 10 & 34 \\
\hline 20 & 43 & 20 & 56 \\
\hline 30 & 95 & 30 & 98 \\
\hline 40 & 100 & 40 & 100 \\
\hline 50 & 82 & 50 & 96 \\
\hline 60 & 24 & 60 & 28 \\
\hline 70 & 0 & 70 & 0 \\
\hline
\end{tabular}

The data presented in Table 3 indicate that the optimum of the catalytic activity in the control samples is in the range of $35-45^{\circ} \mathrm{C}$. For prototypes, this indicator is $28-54{ }^{\circ} \mathrm{C}$.

For 1 hour, the solution with the collagenase enzyme was irradiated with blue light with a radiated flux power of $35 \mu \mathrm{W} / \mathrm{cm} 2$, which led to an increase in the range of biocatalytic activity of the enzyme. These data correlate with the indications obtained in studies using the methods of Teleshevskaya and Anson.

The inhibition of the catalytic activity of the enzyme was studied by the Anson method, which consists in applying a $0.5-4.0 \%$ solution of table salt to gelatin.

Table 4. The Effect on the Activity of Control and Experimental Samples of the Collagenase Enzyme $\mathrm{NaCl}$ at an Optimum $\mathrm{pH}$ of 8 and a Temperature of $41{ }^{\circ} \mathrm{C} ., \%$.

\begin{tabular}{|c|c|c|c|}
\hline \multicolumn{2}{|c|}{ Control } & \multicolumn{2}{|c|}{ Experiment } \\
\hline $\begin{array}{c}\text { Table salt } \\
\text { concentration, } \%\end{array}$ & $\begin{array}{c}\text { Collagenase activity, } \\
\text { units } / \mathrm{mg}\end{array}$ & $\begin{array}{c}\text { Table salt } \\
\text { concentration, } \%\end{array}$ & $\begin{array}{c}\text { Collagenase activity, } \\
\text { units / mg }\end{array}$ \\
\hline 0 & 118 & 0 & 147 \\
\hline 0,5 & 112 & 0,5 & 138 \\
\hline 1 & 104 & 1 & 123 \\
\hline 1,5 & 95 & 1,5 & 111 \\
\hline 2 & 76 & 2 & 69 \\
\hline 2,5 & 52 & 2,5 & 49 \\
\hline 3 & 37 & 3 & 18 \\
\hline 3,5 & 12 & 3,5 & 0 \\
\hline 4 & 0 & 4 & \\
\hline
\end{tabular}

The data presented in the table indicate that table salt is not competitive with an inhibitor of the gelatin cleavage reaction. It changes the location of the enzyme molecule, affecting the degree of collagenase ionization, reducing its activity. It follows from this that the activity of the collagenase enzyme in the experimental samples under the influence of table salt in the concentration range of up to $4 \%$ is $6-29 \mathrm{u} / \mathrm{mg}$ higher than in the control samples. 
Table 5. The Effect on the Activity of Control and Experimental Samples of the Collagenase Enzyme $\mathrm{NaNO} 2$ at an Optimum $\mathrm{pH}$ of 8 and a Temperature of $41{ }^{\circ} \mathrm{C} ., \%$

\begin{tabular}{|c|c|c|c|}
\hline \multicolumn{2}{|c|}{ Control } & \multicolumn{2}{c|}{ Experiment } \\
\hline $\begin{array}{c}\text { Table salt } \\
\text { concentration, } \%\end{array}$ & $\begin{array}{c}\text { Collagenase activity, } \\
\text { units / mg }\end{array}$ & $\begin{array}{c}\text { Table salt } \\
\text { concentration, } \%\end{array}$ & $\begin{array}{c}\text { Collagenase activity, } \\
\text { units } / \mathrm{mg}\end{array}$ \\
\hline 0 & 118 & 0 & 147 \\
\hline 0,1 & 107 & 0,1 & 134 \\
\hline 0,2 & 104 & 0,2 & 119 \\
\hline 0,3 & 98 & 0,3 & 106 \\
\hline 0,4 & 91 & 0,4 & 100 \\
\hline 0,5 & 84 & 0,5 & 95 \\
\hline 0,6 & 78 & 0,6 & 91 \\
\hline 0,7 & 63 & 0,7 & 82 \\
\hline
\end{tabular}

NaNO2 interacting with the substrate at a concentration of up to $0.7 \mathrm{mmol} / \mathrm{dm} 3$ reduces the activity of collagenase in control samples by $46.6 \%$, in experimental samples by $44.2 \%$. This shows that the treatment of the collagenase enzyme with blue light for 1 hour with a luminous flux of $35 \mu \mathrm{W} / \mathrm{cm} 2$ increases the optimal values of its activity and reduces the negative effect of the chemicals $\mathrm{NaCl}$ and $\mathrm{NaNO} 2$.

It was found that the activity of the collagenase enzyme, which was treated with blue light, has a wider optimum $\mathrm{pH}$. Treatment of the solution with blue light collagenase with a luminous flux of $35 \mu \mathrm{W} / \mathrm{cm} 2$ for 1 hour increases the optimum biocatalytic activity of the enzyme, which is confirmed by studies conducted in two alternative methods.

\section{Conclusions}

Solution treatment with blue light collagenase with a luminous flux of $35 \mu \mathrm{W} / \mathrm{cm} 2$ for 1 hour increases the optimum biocatalytic activity of the enzyme, which is confirmed by studies conducted in two alternative methods (according to Anson and Telishevskaya). The experimental data showed that the activity of the collagenase enzyme in the experimental samples increased from 10 to $20 \%$ under the influence of table salt in concentrations up to $3.5 \%$ compared to the control group.

\section{References}

1. O. Yu. Shiryaeva, S. S. Shukshina, Izvestia OGAU 1 (57), 173 (2016).

2. D. V. Karpenko, K. V. Shalaginov, Health, Food \& Biotechnology 1, 83 (2019).

3. A.Yu. Suprunyuk, D.V. Karpenko, University Scientific Conference of Young Scientists and Specialists "Science Day": Sat. mater. - M .: MGUPP, 2016 - Part II. - 181 p. (2016).

4. D. V. Karpenko, V. S. Kravchenko, K. V. Shalaginov, Beer and Drinks 5, 16 (2017).

5. D. N. Fedorin, A. T. Eprintsev, J. of Stress Physiology \& Biochemistry 3, 121 (2017).

6. N. L. Duel, Biotechnol. Acta 2, 115 (2013)

7. I.V. Azizov, F.I. Gasimova, U.F. Ibragimova, K.R. Tagieva, A.B. Abdullaeva, Sciences of Europe 41-1(41), 3 (2019)

8. Yu. Ts. Martirosyan, L. Yu. Martirosyan, A. A. Kosobryukhov, Agricultural Biology 1, 130 (2019)

9. S.K. Apraksina, Development of technology of a protein product from collagencontaining raw materials and its use in the production of boiled sausages: dis ... cand. 
those. Sciences: 05.18.04 / Apraksina Svetlana Konstantinovna. - M.: MGAPB, 1996. $160 \mathrm{p}$.

10. G.S. Bedi, T. Williams, J Biol Chem. 269 (1), 599 (1994). 